KS. PAWEŁ KALETA

Wydział Prawa, Prawa Kanonicznego i Administracji

Katolickiego Uniwersytetu Lubelskiego Jana Pawła II

\title{
KANONICZNE SANKCJE KARNE ZA PRZESTĘPSTWA MAJĄTKOWE
}

Treść: Wprowadzenie. - 1. Prawo Kościoła do stosowania sankcji karnych. - 2. Stosowanie prawa karnego za przestępstwa majątkowe. - 3. Sankcje karne za przestępstwa majątkowe. - Wnioski końcowe.

\section{Wprowadzenie}

Dobra kościelne wymagają ochrony, tak przez przepisy prawa kanonicznego jak również przez zarządców, którzy bezpośrednio sprawują zarząd nad nimi (por. kan. $1279 \$ 1$ ). Przestępstwa majątkowe zarówno w dziedzinie zarządzania jak i alienowania majątkiem kościelnym mogą przyczyniać się do strat finansowych, niepotrzebnego zgorszenia wiernych, jak i osłabienia zaufania publicznego. Kościół, chcąc zaniechać tym przestępstwom, winien szukać skutecznych metod, które pozwolą na przestrzeganie prawa kanonicznego. Jedną $\mathrm{z}$ form przeciwdziałania przestępstwom majątkowym jest kościelne prawo karne zawarte w Księdze VI Kodeksu Prawa Kanonicznego z 1983 roku ${ }^{1}$.

Zmiany obyczajowe, które można zaobserwować w Kościele, błędne zamiany sankcji karnych na rzecz przebaczenia w imię miłości

\footnotetext{
${ }^{1}$ Codex Iuris Canonici auctoritate Ioannis Pauli PP. II promulgatus, A AS 75(1983), II, ss. 1-317; Kodeks Prawa Kanonicznego, przekład polski zatwierdzony przez Konferencję Episkopatu, Poznań 1984 [dalej KPK/1983].
} 
chrześcijańskiej² ${ }^{2}$ sprawiły, że papież Benedykt XVI, decyzją z dnia 25 stycznia 2008 r., zlecił, aby Księga VI KPK/1983 została poddana rewizji, tak, aby dostosować przepisy prawa karnego do obecnej sytuacji w Kościele.

Pytanie, które należy postawić brzmi następująco: jakie są kościelne sankcje karne za przestępstwa w dziedzinie dóbr kościelnych? Przeprowadzenie analizy prawnej przedstawionego problemu wydaje się aktualne również z uwagi na to, że obecnie Papieska Rada Tekstów Prawnych dokonała rewizji Księgi VI KPK/1983 i opublikowała Schema recognitionis Libri VI Codicis Iuris Canonici ${ }^{3}$. Treść schematu została wysłana do Konferencji Biskupów, Kongregacji Kurii Rzymskiej, Wydziałów Prawa Kanonicznego oraz do Konferencji Wyższych Przełożonych Zakonów Męskich i Żeńskich w celu zgłaszania uwag ${ }^{4}$.

\section{Prawo Kościoła do stosowania sankcji karnych}

Kościół posiada wrodzone i własne prawo do wymierzania sankcji karnych przeciwko popełniającym przestępstwo (kan. 1311). Uprawnienie to nadane przez samego Chrystusa ${ }^{5}$ wynika z samej natury Kościoła i wchodzi w zakres munus regendi ordynariusza. Władza ta przysługuje ordynariuszom, posiadającym władzę rządzenia w zakresie zewnętrznym i wewnętrznym i obejmuje ustanowienie sankcji karnych zabezpieczających prawo Boże i prawo kościelne, przy zachowaniu granic kompetencji ze względu na terytorium lub osoby (kan. $1315 \$ 1)$.

\footnotetext{
2 Pontificium Consilium de Legem Textibus, Schema recognitionis Libre VI Codicis Iuris Canonici, Communictiones 43(2011) nr 2, s. 318. [tłumaczenie autora]

${ }^{3}$ Tenże, Schema recognitionis Libre VI Codicis Iuris Canonici (Reservatum), Typis Polyglottis, 2011.

${ }^{4}$ Tenże, Schema recognitionis Libre VI Codicis Iuris Canonici, Communictiones 43(2011) nr 2, s. 317.

${ }^{5}$ Gdy brat zgrzeszył przeciw tobie, idź i upomnij go w cztery oczy. Jeśli cię usłucha pozyskasz swego brata. Jeśli zaś nie usłucha weź ze sobą jeszcze jednego albo dwóch, żeby na słowie dwóch albo trzech świadków oparła się cała prawda. Jeśli i tych nie usłucha, donieś Kościołowi. A jeśli nawet Kościoła nie usłucha, niech ci będzie jako poganin i celnik (Mt 18, 15-17).
} 
Karanie przestępstw ${ }^{6}$ nie jest ostatnim prawem Kościoła, w którym regulowany jest kościelny porządek społeczny, ale jest wezwaniem do nawrócenia ${ }^{7}$. Kanoniczne sankcje karne są środkiem ad animarum salutem procurandum ${ }^{8}$. Papieska Rada Tekstów Prawnych zaleca, aby biskupi stosowali kanoniczne prawo karne niezwłocznie, kiedykolwiek dojdzie do zewnętrznego naruszenia ustawy lub nakazu opatrzonego sankcją karną ${ }^{9}$. Natomiast wszczęcie postępowania sądowego lub administracyjnego celem wymierzenia lub deklaracji kary, zgodnie z kan. 1341, może nastąpić dopiero wtedy, gdy ordyanriusz uznał, że ani braterskim upomnieniem, ani naganą, ani też innymi środkami pasterskiej troski nie można w sposób wystarczający naprawić zgorszenia, wyrównać naruszonej sprawiedliwości i doprowadzić do poprawy winnego.

Prawodawca kościelny w kan. 1341 wskazuje na potrójny cel kary kościelnej: a) naprawienie powstałego zgorszenia, b) wyrównanie naruszonej sprawiedliwości, c) oraz poprawa przestępcy. Wszystkie te cele, w rzeczywistości, sprowadzają się do jednego - poprawy przestępcy i wyrównania naruszonej sprawiedliwości.

Ordynariusz, obok wymierzenia lub deklaracji kary kościelnej na drodze postępowania sądowego lub administracyjnego, może skorzystać ze środków zaradczych i pokuty (kan. $1312 \$ 3$ ). Nie oznacza to jednak, alternatywy zastępczej ustanowionych sankcji karnych, ale

\footnotetext{
${ }^{6}$ Prawodawca nie podaje definicji przestępstwa, pozostawiając jej sformułowanie doktrynie. Według kan. $1321 \$ 1$ naruszenie ustawy lub nakazu tylko wtedy podlega karze, gdy jest ciężko poczytalne na skutek winy umyślnej albo nieumyślnej. Zob. A.G. Miziński, Przestępstwo, w: Encyklopedia Katolicka, t. 16, Lublin 2012, kol. 701-704.

${ }^{7}$ Por. P. Gajda, Sankcje karne w Kościele w świetle Kodeksu Prawa Kanonicznego Jana Pawła II oraz późniejszych zmian i uzupełnień. Studium kanoniczno-pastoralne, Tarnów 2008, s. 12.

${ }^{8}$ Por. T. Pawluk, Prawo kanoniczne wedtug Kodeksu Jana Pawła II. Doczesne dobra Kościoła. Sankcje w Kościele. Procesy, t. IV, Olsztyn 2009, s. 65.

${ }^{9}$ Pontificium Consilium de Legem Textibus, Quaestiones quaedam studio Pontificii Consilii Submissae, Communicationes 43(2011), s. 318. [tłumaczenie autora]
} 
stanowi dla ordynariusza możliwość wyboru, z jakich praw skorzystać, aby naruszona sprawiedliwość została przywrócona.

\section{Stosowanie prawa karnego za przestępstwa majątkowe}

Prawodawca kościelny w Księdze VI KPK/1983 nie określa sankcji karnej za przestępstwa majątkowe, które potocznie mogą być rozumiane jako: kradzież, defraudacja dóbr kościelnych czy nadużywanie zastrzeżonych znaków towarowych itp. Co więcej, prawodawca w KPK/1983 nie używa pojęcia „przestępstwo majątkowe”. Jednakże w Księdze VI KPK/1983 można znaleźć dziewięć przykładów, które mają zastosowanie do przestępstw majątkowych. Do tych przepisów należy:

1. Utrudnianie w korzystaniu $\mathrm{z}$ dóbr kościelnych (kan. 1375),

2. Dokonanie nieważnej alienacji (kan. 1377),

3. Przestępstwo symonii (kan. 1380),

4. Nielegalne zyski z ofiar mszalnych (kan. 1385),

5. Przestępstwo przekupstwa (kan. 1386),

6. Nadużycie władzy lub zadania (kan. $1389 \$ 1$ ),

7. Niedbałe wykonanie aktów władzy kościelnej (kan. $1389 \$ 2$ ),

8. Sporządzenie fałszywego dokumentu (kan. 1391, $1^{\circ}$ ),

9. Prowadzenie handlu przez duchownych (kan. 1392).

Ad.1. Utrudnianie w korzystaniu $z$ dóbr kościelnych kan. 1375

Prawo własności dóbr należy do tej osoby prawnej (publicznej lub prywatnej), która zgodnie z prawem je nabyła (kan. 1256). Dobra kościelne są środkiem do realizacji misji Kościoła i nie mają celu samego dla siebie ${ }^{10}$. Natomiast prawne korzystanie $\mathrm{z}$ dóbr kościelnych polega na ich używaniu zgodnie z własnymi celami, którymi są: organizowanie kultu Bożego, zapewnienie godziwego utrzymania duchowieństwa oraz innych pracowników kościelnych, prowadzenie dzieł apostolatu i miłości zwłaszcza wobec biednych (kan. 1254 $\$ 2)$. Do przestępnych działań skierowanych przeciwko swobodnemu korzystaniu z dóbr kościelnych należy zaliczyć te, które utrudniają

${ }^{10}$ Por. P. Kaleta, Kościelne prawo majątkowe, Lublin 2014, s. 7. 
lub wręcz uniemożliwiają używanie tychże dóbr zgodnie z ich prawnym przeznaczeniem ${ }^{11}$. Przykładem może być uzurpowanie dóbr kościelnych jako majątku własnego oraz używania ich do własnych celów, czerpiąc równocześnie $\mathrm{z}$ nich dochody ${ }^{12}$. Tego typu działania kwalifikują się jako utrudnianie w korzystaniu z dóbr kościelnych. Sprawca tego przestępstwa może zostać ukarany sprawiedliwą karą ferendae sententiae (kan. 1375).

Ad. 2. Dokonanie nieważnej alienacji (kan. 1377)

Alienacja jest aktem administracyjnym, którego skutkiem jest przeniesienie prawa własności z jednego podmiotu na drugi tytułem darowizny, sprzedaży lub zamiany ${ }^{13}$. Do jego ważności wymagane jest zezwolenie kompetentnej władzy kościelnej, zgody organów doradczych, zainteresowanych osób oraz wyszczególnienia alienacji już wcześniej dokonanych. Zgodnie z kan. 1377 za brak przepisanego prawem zezwolenia kompetentnej władzy na alienację powinien być ukarany sprawiedliwą karą ${ }^{14}$.

Kan. 18 stanowi, że ustawy, które ustanawiają kary podlegają ścisłej interpretacji. Dlatego kan. 1377 należy interpretować ściśle. W związku z tym, przestępstwo dokonania nieważnej alienacji, będzie dotyczyło alienacji sensu stricto. Tego kanonu nie należy stosować w przypadku transakcji, które mogą pogorszyć stan majątku kościelnego (kan. 1295) oraz umów dzierżawy (kan.1297). Sprawca, który dokonał alienacji sensu stricto bez przepisanego prawem zezwolenia

\footnotetext{
${ }^{11}$ Por. J. Syry jCzy , Kanoniczne prawo karne. Część szczególna, Warszawa 2003, s. 88 .

${ }^{12}$ Por. T. Pawluk, Prawo kanoniczne..., s. 136.

${ }^{13}$ Szerzej zob. F. Grazian, La nozione di amministrazione e di alienazione nel Codice di diritto canonico, Roma 2002; L. Świto, Alienacja majątku kościelnego $w$ diecezjach rzymskokatolickich $w$ Polsce, Olsztyn 2010, s. 89.

${ }^{14}$ Kan. 1377 odnosi się do kan. 1296, który określa, że jeśli dobra kościelne zostały alienowane bez zachowania formalności przepisanych prawem kościelnym, lecz ważnej według prawa państwowego, do kompetentnej władzy należy decyzja, po dokładnym rozważeniu wszystkiego, czy i jaką skargę, mianowicie osobową lub rzeczową, przez kogo i przeciw komu, należy wnieść dla odzyskania praw Kościoła.
} 
powinien być ukarany sprawiedliwą karą ferendae sententiae (kan. 1377). Prawo partykularne, w miejsce nieokreślonej kary ferendae sententiae może ustanowić karę określoną lub obowiązkową (kan. $1315 \S 3)$.

\section{Ad. 3. Przestępstwo symonii (kan. 1380)}

Zgodnie z tradycją Kościoła szafarz sprawujący sakramenty święte ma prawo do otrzymania ofiary, która nie jest zapłatą za udzielony sakrament. Ofiary składane z racji Mszy św. nie stanowią przestępstwa symonii (zob. kann. 945-958). Kwestię dotyczącą wielkości składanych ofiar z okazji udzielania sakramentów reguluje ustawodawstwo partykularne (kan. 1264).

Przestępstwo symonii polega na sprawowaniu lub przyjmowaniu sakramentu ze świadomą intencją kupowania lub sprzedawania sakramentu w zamian za dobra doczesne ${ }^{15}$. Symonia określana jest również świętokupstwem, będącą świadomą wolą kupienia, sprzedania lub zamienienia sakramentu za cenę doczesną ${ }^{16}$. Kan. 1380 nie stosuje się do sakramentaliów, ale wyłącznie do sakramentów ${ }^{17}$. Karę powinien ponieść zarówno udzielający sakramentu jak i przyjmujący sakrament. Przestępstwo jest dokonane wówczas, gdy umowa symoniacka zostanie zrealizowana przez faktyczne udzielenie sakramentu $^{18}$. Sankcja karna dla osoby świeckiej to obligatoryjny interdykt ferendae sententiae, natomiast sankcja karna dla osoby duchownej suspensa lub interdykt ferendae sententiae ${ }^{19}$. Wymierzenie kary jest obligatoryjne, ale sędzia nie jest zobowiązany, aby duchownemu

\footnotetext{
${ }^{15}$ Por. A. G. Mızıński, Symonia, w: Encyklopedia Katolicka, t. 18, Lublin 2013, kol. 1315-1316.

${ }^{16}$ Por. T. Pawluk, Prawo kanoniczne..., s. 140.

${ }^{17}$ Por. F.G. Morrisey, Financial malfeasance and church law, Vancouver 2013, s. 8. Dokument niepublikowany w posiadaniu autora artykułu.

${ }^{18}$ Por. J. Syry JCzy , Kanoniczne prawo karne..., s. 109; Inaczej twierdzi E. SztaFrowski, który sądzi, że umowa nie musi być skuteczna, Podręcznik prawa kanonicznego, t. IV, Warszawa 1986, s. 359.

${ }^{19}$ Por. J. Arias, Księga VI. Sankcje w Kościele, w: Kodeks Prawa Kanonicznego. Komentarz, red. P. Majer, Kraków 2011, s. 1034.
} 
wymierzyć suspensę. Może - ze względu na zachodzące okoliczności - wymierzyć karę interdyktu ${ }^{20}$.

Ad. 4. Nielegalne zyski z ofiar mszalnych (kan. 1385)

Kościół aprobuje zwyczaj składania ofiar mszalnych z okazji ich celebrowania (zob. kan. $945 \$ 1-2$ ). Nie stanowią one formy zapłaty jak i warunku sprawowania sakramentu. Przyjmowanie ofiar z okazji celebrowania Mszy św. nie może mieć charakteru transakcji czy handlu (kan. 947), ponieważ czynność ta byłaby przestępstwem symonii, którą zakazuje prawo Boże ${ }^{21}$. Kościół zabiega o zachowanie właściwego znaczenia przyjmowania ofiar mszalnych i jednoczenie zapobiega przed możliwością nadużyć. Nielegalne zyski z ofiar mszalnych najczęściej przyjmują formę manipulacji stypendiami, które mogą przejawiać się następująco:

a) gromadzenia wysokich stypendiów celem późniejszego ich odstąpienia innym z pomniejszoną kwotą (kan. $955 \$ 1$ ),

b) zbieranie stypendiów zagranicznych z zamiarem ich dystrybucji na korzystnych warunkach w walucie krajowej,

c) gromadzenie stypendiów dla innych w celu uzyskania od nich określonej części złożonych ofiar ${ }^{22}$,

d) łączenie intencji mszalnych związanych z poszczególnymi stypendiami mszalnymi wbrew kan. 948, należy odprawić tyle Mszy św. ile intencji zostało przyjętych bez względu na wielkość złożonej ofiary,

e) przyjmowanie dla siebie więcej niż jedno stypendium mszalne dziennie ze Mszy św. binowanej lub trynowanej ${ }^{23}$. Wyjątek stanowi dzień Bożego Narodzenia (kanon 951, § 1),

\footnotetext{
${ }^{20}$ Por. J. Sy ryjCzy K, Kanoniczne prawo karne..., s. 110.

${ }^{21}$ Por. M. Pastuszko, Najświętsza Eucharystia według Kodeksu prawa Kanonicznego Jana Pawła II, Kielce 1997, s. 368.

${ }^{22}$ Por. T. J. Green, Book VI. Sanctions in the Church cc.1311-1399, w: New Commentary on the Code of Canon Law, red. J.P. Beal, J.A. Corriden, T. J. Green, New York 2000, s. 1590.

${ }^{23}$ Por. B. Nowakowski, Czy proboszcz może przyjać każdego dnia jedno stypendium mszalne?, Prawo Kanoniczne 53(2010) nr 1-2, s. 147-157.
} 
g) nieuzasadnione podwyższanie wynagrodzenia $\mathrm{z}$ tytułu zewnętrznego (np. śpiewu) w przypadku przekazywania ofiar z binacji na cele oznaczone przez ordynariusza (kan. $951 \S 1$ ),

h) domaganie się od ofiarodawcy większej wartości stypendium mszalnego, aniżeli określa to prawo partykularne lub miejscowy zwyczaj (kan. $952 \$ 1-2$ ),

i) aplikowanie Mszy św. zbiorowych więcej niż dwa razy w tygodniu ${ }^{24}$.

Podmiotami tych przestępstw mogą być duchowni, zakonnicy, osoby świeckie, mające udział w zbieraniu lub rozdzielaniu stypendiów mszalnych. Za uzyskanie nielegalnych zysków z ofiar mszalnych prawodawca przewiduje obligatoryjną karę ferendae sententiae. Sprawca powinien być ukarany cenzurą (np. ekskomuniką lub interdyktem lub suspensą) lub inną sprawiedliwą karą. Rodzaj cenzury nie został określony (kan. 1385).

\section{Ad. 5. Przestępstwo przekupstwa (kan. 1386)}

Zgodnie z kan. 1386 przestępstwa przekupstwa dopuszcza się ten, kto udziela lub obiecuje udzielić jakiejś korzyści majątkowej lub osobistej wykonującemu zadanie kościelne, w celu skłonienia go do działania lub zaniechania stanowiącego naruszenie przepisu prawa. Przestępstwo przekupstwa dotyczy zarówno osoby udzielającej korzyści majątkowej (przekupstwo czynne) jak i osoby obdarowanej korzyścią majątkową (przekupstwo bierne). Korzyścią majątkową może być każde dobro, które zaspokoi daną potrzebę, a wartość udzielonego dobra da się wyrazić w pieniądzu ${ }^{25}$. Za przekupstwo uznaje się bez względu na to, która strona wystąpiła z inicjatywą oraz czy cel został osiągnięty ${ }^{26}$.

Kan. 1386 koresponduje $\mathrm{z}$ kan. 1456, w którym prawodawca zabrania sędziemu i wszystkim pracownikom trybunału przyjmować

\footnotetext{
${ }^{24}$ Por. P. Gefaell, A proposito del decreto sulle messe plurintenzionali, Ius Ecclesiae 3(1991) nr 4, s. 760-765.

${ }^{25}$ Por. J. Syry JCzy k, Kanoniczne prawo karne..., s. 122.

${ }^{26}$ Por. T. Pawluk, Prawo kanoniczne..., s. 141.
} 
jakichkolwiek podarunków z okazji prowadzenia sprawy, zabrania pełnomocnikom i adwokatom wykupywać sporu (kan. $1488 \$ 1$ ) oraz przyjmować podarunków (kan. 1489).

Za udział w przestępstwie przekupstwa zarówno czynnego jak i biernego jest obligatoryjna kara ferendae sententiae. Sprawca ma być ukarany sprawiedliwą karą. Wielkość wymierzenia kary jest uzależniona od dokonanego przestępstwa. W wymierzeniu kary sędzia może odnieść się do kan. 1344 i kan. 1349.

\section{Ad. 6. Nadużycie władzy lub zadania (kan. 1389 \$ 1)}

Podstawową zasadą rewizji soborowej odnowy Kościoła, było uznanie, że władza ma być wykonywana w duchu służby Kościołowi ${ }^{27}$. Dlatego każde nadużycie władzy (potestas) lub zadania ( $m u-$ nus) będzie polegało na użyciu władzy lub zadania do innych celów niż te, do których powinny zmierzać np. do uzyskania własnych korzyści lub dla wyrządzenia komuś szkody ${ }^{28}$. Nadużyciem jest także sprawowanie władzy w sposób bezprawny ${ }^{29}$. Przestępstwem jest nadużycie każdej władzy kościelnej: władzy święceń, władzy rządzenia (ustawodawczej, wykonawczej i sądowniczej), władzy zwyczajnej i delegowanej, dotyczącej zakresu zewnętrznego i wewnętrznego, a także władzy zwierzchniej ${ }^{30}$. Tak szeroki zakres władzy kościelnej wynika z faktu, że w kan. 1389 prawodawca nie czyni żadnych ograniczeń zakresu władzy, ani też nie dokonuje jej podziału ${ }^{31}$.

\footnotetext{
${ }^{27}$ Por. Ioannes Paulus PP. II, Constitutio apostolica Sacrae Disciplinae Leges (25.01.1983), AAS 75 part II (1983), pp. VII-XIV.

${ }^{28}$ Por. W. Wójcıк, Księga VI. Sankcje w Kościele, w: W. Wójcik, J. Krukowski, F. Lempa, Komentarz do Kodeksu z 1983 r. Księga V. Dobra doczesne Kościoła. Księga VI. Sankcje w Kościele, t. IV, Lublin 1987, s. 265.

${ }^{29}$ Por. J. Syryjczy K, Kanoniczne prawo karne..., s. 135.

${ }^{30}$ Por. T. Pawluk, Prawo kanoniczne..., s. 144.

${ }^{31}$ Niektórzy kanoniści twierdzą, że pojęcie władzy kościelnej w kan. 1389 oznacza tylko władzę rządzenia, czyli ustawodawczą, wykonawczą i sądowniczą. Por. A. CALABrese, Diritto penale canonico, Città del Vaticano 1996, s. 332; D. Cito, Le pene per i singoli delitti, w: V. De Paolis, D. Cito, Le sanzioni nella Chiesa. Commento al Codice di Diritto Canonico. Libro VI, Roma 2001, s. 349-350.
} 
Do zaistnienia przestępstwa związanego z nadużyciem władzy lub zadania wymagana jest wina umyślna ${ }^{32}$. Z kan. $1321 \$ 1$ wynika, że wina umyślna polega na dobrowolnym pogwałceniu prawa. Jest to więc zła wola, świadomie skierowana na naruszenie ustawy karnej. O powstaniu winy decydują dwa elementy: a) znajomość ustawy, przeciwko której zwraca się działanie lub zaniechanie sprawcy b) wolność wyboru i wolność w działaniu lub zaniechaniu ${ }^{33}$.

Przestępstwo nadużywania władzy lub zadania w zakresie dóbr kościelnych może przejawiać się: $\mathrm{w}$ przetrzymywaniu zbiórek pieniędzy przeznaczonych na inne cele, niż parafialne (kan. 1266), używanie pieniędzy parafialnych do własnych celów (kan. 1256), przyjmowanie ofiar z obciążeniem określającym sposób korzystania lub stanowiącym warunek bez uprzedniego zezwolenia ordynariusza (kan. 1267 $\$ 2$ ), przeznaczenie ofiar wiernych na inny cel, niż była intencja ofiarodawcy (kan. $1267 \$ 3$ ), nie płacenie podatku diecezjalnego (kan. 1263), nieuzyskanie pisemnego upoważnienia przed dokonaniem aktów nadzwyczajnego zarządzania (kan. $1281 \$ 1$ ), brak uzyskania zgody ordynariusza na inwestowanie majątku na korzyść kościelnej osoby prawnej (kan. $1284 \$ 2,6^{\circ}$ ), nieprzestrzeganie przepisów państwowych dotyczących prawa pracy i życia społecznego (kan. 1286, $1^{\circ}$ ), brak uzyskania pisemnego zezwolenia własnego ordynariusza dla wszczęcia sprawy w sądzie państwowym (kan. 1288), samowolne porzucanie przyjętych zadań munus (kan. 1289), niezachowanie przepisów dotyczących alienacji dóbr należących do patrimonium stabile (kan. 1291-1294), brak uzyskania pisemnego zezwolenia ordynariusza na przyjęcie pobożnej fundacji nieautonomicznej (kan. $1304 \$ 1$ ), redukcja lub przeniesienie fundacyjnych zobowiązań mszalnych bez zachowania przepisów (kann. 1308-1309).

Prawodawca kościelny za nadużycie władzy lub zadania, nakłada obowiązek nałożenia kary ferendae sententiae na osobę, która

\footnotetext{
${ }^{32}$ Por. F. Lempa, Przestępne nadużycie władzy kościelnej w prawie powszechnym Kościoła łacińskiego, Lublin 1991, s. 304-306.

${ }^{33}$ Por. M. Myrcha, Problem winy w karnym ustawodawstwie kanonicznym, Prawo Kanoniczne 29(1986) nr 1-2, s. 43-80.
} 
nadużyła władzy kościelnej lub powierzonego zadania (kan. $1389 \$ 1$ ). Wielkość kary, jaką obwiniony powinien ponieść jest uzależniona od ciężkości przestępstwa. Prawodawca nie wyklucza kary pozbawienia urzędu. W mocy należy zachować kan. 1349, który stanowi: „Jeśli kara jest nieokreślona, a ustawa czego innego nie zastrzega, sędzia nie powinien wymierzać cięższych kar, zwłaszcza cenzur, chyba że domaga się bezwzględnie ciężkość przypadku".

Ad. 7. Niedbałe wykonanie aktów władzy kościelnej (kan. 1389 \$2)

Niedbałe wykonanie aktów władzy kościelnej polega na braku staranności przy podejmowaniu aktów władzy lub zadań kościelnych, przejawiający się w bezprawnym działaniu lub zaniechaniu wynikający z winy nieumyślnej, powodującą czyjąś szkodę materialną lub moralną. Prawodawca w kan. $1389 \$ 2$ odwołuje się do winy nieumyślnej (culpa), w odróżnieniu do $\$ 1$, w którym mowa jest winie umyślnej (dolus). Do zaistnienia szkody konieczne jest faktyczne jej spowodowanie przez wykonanie nielegalnego aktu powodującego naruszenie czyichś praw podmiotowych.

Czynności podejmowane przez sprawcę lub zaniechane muszą dotyczyć nielegalnego aktu władzy kościelnej, posługi lub zadania. Będą to czynności, które znamionuje brak należnej staranności tak, że akt narusza prawo i powoduje szkodę.

Podmiotami dokonującymi niedbałych aktów władzy kościelnej mogą być zarówno osoby duchowne jak i świeckie (kan. 1282). Przestępstwa niedbałego wykonania aktów władzy kościelnej w zakresie dóbr kościelnych mogą przejawiać się w następujących działaniach: wykorzystanie ofiar wiernych do celów innych, niż zostały wskazane przez darczyńcę (kan. 949; kan. 1267, \$3; kan. 1300; kan. 1303, $\$ 2$ ), wypełnianie zadań bez zachowania staranności „dobrego ojca rodziny" (kan. $1284 \$ 1$ ), nieprzestrzeganie prawa państwowego dotyczące dóbr kościelnych (kan. 1274, $\$ 4-5$, kan. 1284, $\$ 2,2^{\circ}-3^{\circ}$ ), dokonanie ważnych aktów nadzwyczajnego zarządzania ale niezgodnych z prawem (kan. $1281 \S 3$ ), sporządzenie niedokładnych ksiąg inwentarzowych oraz brak ich aktualizacji (kan. 1283, $2^{\circ}-3^{\circ}$ ), brak zachowania czujności aby powierzone dobra nie przepadły lub nie 
doznały jakiejś szkody, zawierając w tym celu odpowiednie umowy ubezpieczające (kan. $1281 \$ 2,1^{\circ}$ ), niezabezpieczenie dóbr kościelnych środkami ważnymi według prawa państwowego (kan. $1284 \$ 2,2^{\circ}$ ), nieprzestrzeganie przepisów prawa kanonicznego, jak i państwowego, albo wydanych przez fundatora ( $\operatorname{kan} .1284 \$ 2,3^{\circ}$ ), niepobieranie we właściwym czasie dochodów $\mathrm{z}$ dóbr i należności, a pobranych nie używanie zgodnie $\mathrm{z}$ wolą fundatora albo $\mathrm{z}$ normami prawnymi (kan. $1284 \$ 2,4^{\circ}$ ), brak systematycznego wpłacania rat należnych $z$ tytułu pożyczki lub zastawu (kan. $1284 \$ 2,5^{\circ}$ ), brak należycie prowadzonych ksiąg przychodów oraz rozchodów (kan. $1284 \$ 2,7^{\circ}$ ), brak sporządzanego sprawozdania pod koniec każdego roku (kan. $1284 \$ 2,8^{\circ}$, kan. 1287 \$1), brak należytego przechowywania dokumentów i dowodów, na których opierają się prawa Kościoła lub instytucji do majątku (kan. $1284 \S 2,9^{\circ}$ ), brak przygotowania rocznego budżetu, jeśli jest to wymagane przez prawo partykularne (kan. $1284 \$ 3$ ), dokonywanie darowizn $z$ dóbr innych niż ruchomych na cele pobożności lub miłości chrześcijańskiej (kan. 1285), niezachowanie przepisów państwowych w zawieraniu umów (kan. 1290), nie przestrzeganie przepisów dotyczących dzierżawy (kann. 1297-1298), niezachowanie przepisów prawa w wypełnianiu testamentów (kan. $1299 \$ 2$ ), brak poinformowania ordynariusza o przyjęciu rozporządzeń inter vivos oraz in mortis causa (kan. $1301 \$ 1$ ), nieprzekazanie dóbr na instytucję, o której mowa w kan. $1274 \$ 1$ po wygasłej fundacji nieautonomicznej (kan. $1303 \$ 2$ ), brak sporządzenia na piśmie ustnego przyjęcia pobożnej fundacji nieautonomicznej (kan. $1306 \$ 1$ ), brak sporządzenia wykazu obowiązków wynikających z pobożnych fundacji (kan. $1307 \$ 1$ ).

Prawodawca w kan. $1389 \$ 2$ nakłada obowiązek nałożenia kary ferendae sententiae. Wielkość kary, jaką obwiniony powinien ponieść jest uzależniona od ciężkości wyrządzonej szkody i okoliczności popełnionego przestępstwa (kan. 1349). Sprawca przestępstwa niezależnie od ukarania, jest zobowiązany do naprawienia wyrządzonej szkody (kan. 128). 
Ad. 8 Sporzadzenie fatszywego dokumentu (kan. 1391, $1^{\circ}$ )

Podstawowym przedmiotem ochrony prawno-karnej wyrażonej w kan. $13911^{\circ}$ i $3^{\circ}$ jest prawda, jaką winien zawierać publiczny dokument kościelny. Przez kościelny dokument publiczny należy rozumieć dokument urzędowy, sporządzony przez reprezentanta kościelnej osoby prawnej z zachowaniem formalności przepisanych prawem (kan. $1540 \$ 1$ ). Działanie przestępne w dziedzinie dóbr kościelnych może przejawiać się jako: podrabianie lub przerabianie kościelnego dokumentu publicznego potwierdzającego prawo własności, zniszczenie urzędowego dokumentu kościelnego lub ukrycie dokumentu np. potwierdzającego otrzymaną darowiznę na kościelną osobę prawną (kan. $1284 \$ 2,9^{\circ}$ ) fałszowanie przygotowanego rocznego budżetu (kan. $1284 \$ 3$ ) jak i rocznego sprawozdania (kan. $1284 \$ 2,8^{\circ}$ ), fałszowanie przychodów i wydatków (kan. 493), fałszowanie celu przeznaczenia ofiary przez ofiarodawcę (kan. $1267 \$ 3$ ), fałszowanie księgi inwentarzowej (kan. 1283, 20), fałszowanie aktu fundacyjnego (kan. 1306), fałszowanie księgi zobowiązań fundacyjnych (kan. $1307 \$ 2$ ), fałszowanie księgi stypendiów mszalnych (kan. 958).

Celem takiego działania musi być wykazanie lub ukrycie jakiegoś faktu lub okoliczności mogących mieć znaczenie prawne ${ }^{34}$. Fałszowanie dokumentu oraz posługiwanie się nim stanowi przestępstwo, za które sprawca może być ukarany sprawiedliwą karą ferendae sententiae (kan. 1391, 1). Brak jest natomiast sankcji karnej. Sędzia, zgodnie ze swoim sumieniem i roztropnością, powinien dostosować ją do ciężaru popełnionego przestępstwa. Ponadto jest zobowiązany kierować się zasadami, o których mowa w kan. 1349.

Ad. 9. Prowadzenie handlu przez duchownych (kan. 1392)

Prawodawca w kan. 286 zabrania duchownym uprawiania handlu i przeprowadzenia transakcji zarówno osobiście, jak też przez inne osoby, zarówno na korzyść własną, jak też na korzyść innych z wyjątkiem tych wypadków, gdy czynione jest to za zgodą władzy kościelnej.

\footnotetext{
${ }^{34}$ Por. T. Pawluk, Prawo kanoniczne..., s. 147.
} 
W kanonicznym porządku prawnym przekroczenie powyższych zakazów zagrożone jest karą nieokreśloną ferendae sententiae.

Sprawcami tych przestępstw mogą być duchowni diecezjalni jak i zakonni, gdy osobiście prowadzą działalność handlową lub przeprowadzają transakcje lub czynią to za pośrednictwem innych osób np. na podstawie zlecenia ${ }^{35}$. Przestępstwem jest tu uprawianie w sposób stały i zorganizowany handlu, którego celem jest odniesienie korzyści materialnej. Powszechnie uznaje się, że sprzedaż gazet, książek lub dewocjonaliów przy Kościele nie jest działalnością handlową ${ }^{36}$.

\section{Sankcje karne za przestępstwa majątkowe}

Przestępstwa majątkowe, będące przedmiotem analizy niniejszych rozważań w większości przypadków są obligatoryjnymi karami ferendae sententiae, bez określonej sankcji karnej (kan. $1315 \$ 2$ ). W takim przypadku wymierzenie kary należy do sędziego lub przełożonego. Brak określonej sankcji karnej daje możliwość sędziemu wymierzenia kary, dostosowanej do ciężaru przestępstwa (zob. kan. 1349), okoliczności i indywidualnych cech sprawcy, tak aby spełniała wymogi sprawiedliwej kary ${ }^{37}$. W przestępstwach majątkowych, obok nieokreślonej sankcji karnej, prawodawca określa trzy przypadki, dla których została określona sankcja karna. Do nich należy: przestępstwo symonii (kan. 1380), nielegalne zyski z ofiar mszalnych (kan. 1385) oraz nadużycie władzy lub zadania (kan. $1389 \$ 1$ ).

W przypadku symonii przepisana sankcja karna dla osoby świeckiej to obligatoryjna cenzura (interdykt) ferendae sententiae natomiast dla duchownego suspensa lub interdykt ferendae sententiae (kan. 1380).

W przypadku nielegalnych zysków z ofiar mszalnych, sankcja karna jest fakultatywna. Sprawca może być ukarany cenzurą (tzn.

\footnotetext{
${ }^{35}$ Por. J. Sy ry jCzy K, Kanoniczne prawo karne..., s. 154.

${ }^{36}$ Por. F.G. Morrisey, Financial Malfeasance and Church, Vancouver 2013. Dokument niepublikowany w posiadaniu autora.

${ }^{37}$ Por. J. Syry jсzy к, Sankcje karne. Część ogólna. Komentarz, Warszawa 2008, s. 280.
} 
ekskomuniką, interdyktem lub suspensą), jednak rodzaj cenzury nie został określony (kan. 1385). Sędzia lub przełożony zamiast cenzury może również wymierzyć którąś z kar ekspiacyjnych.

W przypadku nałożenia cenzury sprawca przestępstwa winien uprzednio otrzymać od ordynariusza przynajmniej jedno ${ }^{38}$ upomnienie, w którym zawarta jest groźba wymierzenia sankcji karnej oraz powinien uzyskać odpowiedni czas, który pozwoli mu na odstąpienie od uporu oraz poprawę (por. kan. $1347 \$ 1)^{39}$. Należy uważać, że sprawca przestępstwa odstąpił od uporu, jeśli rzeczywiście żałował za popełnione przestępstwo, a ponadto odpowiednio naprawił szkody lub przynajmniej poważnie przyrzekł naprawienie szkody (por. kan. $1347 \$ 2$ ).

Kara cenzury za przestępstwo symonii i nielegalnych zysków $\mathrm{z}$ ofiar mszalnych, zgodnie z kan. 1349 in fine, nie może być wymierzona na stałe (perpetuae poenae), a sprawca wymienionych przestępstw nie może być pozbawiony urzędu ani wydalony ze stanu duchownego, ponieważ kara wydalenia ze stanu duchownego może być ustanowiona tylko w prawie powszechnym $(\text { kan. } 1317)^{40}$.

Możliwość pozbawienia urzędu, prawodawca kościelny przewiduje w przypadku przestępstwa nadużycia władzy i zadania (kan. 1389 $\$ 1)$. Podobny wymiar kary stanowi kan. 1741, 5º, który nie należy do Księgi VI poświęconej Sankcjom w Kościele, ale do Księgi VII poświęconej Procesom. W cytowanym wyżej kanonie prawodawca określa, że jedną z przyczyn, dla których proboszcz może być usunięty

\footnotetext{
${ }^{38}$ Kan. 1347 nie wyklucza wielokrotności upomnień. Dwukrotne upomnienie wymagane jest $\mathrm{w}$ kan. $697,2^{\circ} \mathrm{w}$ postępowaniu przy wydaleniu członka $\mathrm{z}$ instytutu życia konsekrowanego.

${ }^{39}$ Por. D. Borek, Uprawnienia i obowiązki ordynariusza w początkowej fazie wymiaru kar (kann. 1341-1342), Prawo Kanoniczne 50(2007) nr 3-4, s. 255-290.

${ }^{40}$ Por. F.G. Morrisey, Financial Malfeasance and Canon Law, presented to the Diocesan Fiscal Management Conference, Houston, Texas, 25 Września 2012 (dokument niepublikowany); J.A. Renken, Penal Law and Financial Malfeasance, Studia Canonica 42(2008), s. 5-57; zob. szerzej: Z. Suchecki, Wydalanie duchownych na podstawie kanonicznego procesu karnego, Prawo Kanoniczne 54(2011) nr 3-4, s. 77-115.
} 
z parafii - jest „złe zarządzanie dobrami doczesnymi, z wielką szkodą Kościoła, ilekroć na zaradzenie złu brak jest innego środka". Choć prawodawca nie stosuje gradacji sankcji karnych w Kościele, to jednak wydaje się, że kara pozbawienia urzędu może należeć do najcięższych kar, którą można zakwalifikować jako karę ekspiacyjną (zob. kan. $\left.1336 \$ 1,2^{\circ}\right)$. Sprawca może skorzystać z prawa do rezygnacji $\mathrm{z}$ urzędu kościelnego (kan. 187), aby pokazać swoje szczere pragnienie swej poprawy oraz dla przywrócenia utraconego zaufania strony, która została pokrzywdzona. Jeśli zaś sprawca nie chce zrezygnować ze swego urzędu, wówczas biskup diecezjalny może skorzystać z procesu sądowego lub administracyjnego i pozbawić go urzędu zgodnie z przepisami prawa ${ }^{41}$. Chcąc tego dokonać, ordynariusz lub inna osoba przez niego wyznaczona zobowiązana jest do przeprowadzenia dochodzenia wstępnego (kan. $1717 \$ 1$ ). Sądzić należy, że dochodzenie wstępne ma na celu zebranie wszelkich informacji na temat przedmiotu i podmiotu przestępstwa, poczytalności sprawcy, okoliczności popełnienia przestępstwa, które mogą przyczynić się do złagodzenia lub obciążenia kary ${ }^{42}$. W przypadku notorycznego przestępstwa i niebudzącego wątpliwości dochodzenie wstępne jest zbędne (kan. 1717 in fine).

Dopiero po zebraniu wystarczającego materiału dochodzeniowego, ordynariusz winien zdecydować: a) czy może być wszczęty proces, b) czy taki proces jest korzystny biorąc pod uwagę kan. 1341, c) oraz czy należy zastosować proces sądowy, lub posłużyć się dekretem

\footnotetext{
${ }^{41}$ Wikariusz generalny i biskupi mogą być odwołani w sposób nieskrępowany przez biskupa diecezjalnego (kan. $477 \$ 1$ ), wikariusz sądowy, pomocniczy wikariusze sądowi, w trakcie trwania kadencji mogą być usunięci z powodu prawnie uznanej i poważnej przyczyny (kan. 1422), kanclerz, wicekanclerz, notariusz mogą być usunięci z powadu poważnej przyczyny (kann. $193 \$ 1-2 ; 194 ; 195)$ ), ekonom diecezjaalny może być usunięty w trakcie trwania kadencji po wysłuchaniu zdania kolegium konsultorów oraz rady do spraw ekonomicznych (kan. $494 \$ 2$ ), proboszcz, który zarządza majątkiem kościelnym może zostać usunięty z urzędu zgodnie z przepisami prawa zawartymi w kan. 1740-1747.

${ }^{42}$ Por. F. LozA, Proces karny, w: Kodeks Prawa Kanonicznego. Komentarz, red. P. Majer, Kraków 2011, s. 1290.
} 
pozasądowym (kan. 1718, § 1). Ordynariusz może dopiero wtedy rozpocząć proces karny gdy uznał, że ani braterskim upomnieniem, ani naganą, ani też innymi środkami pasterskiej troski nie można w sposób wystarczający naprawić zgorszenia, wyrównać naruszonej sprawiedliwości i doprowadzić do poprawy winnego (kan. 1341).

W zależności od okoliczności w jakich przestępstwo zostało dokonane (w szczególności brak rozgłosu), wówczas wszczęcie procesu sądowego może wydać nie konieczne, a skuteczne okazać się mogą inne środki krane (kan. 1339) lub pokuty (kan. 1340). Ten rodzaj rozwiązania ma zastosowanie, jeśli sprawca jest gotów do naprawienia szkody i rzeczywiście żałował popełnienia przestępstwa (kan. 1347 $\$ 2)$. Zastosowanie środków mediacji również może okazać się pomocne w przeciwdziałaniu wszczęcia procesu sądowego ${ }^{43}$.

\section{Wnioski końcowe}

Księga VI KPK/1983 zawiera dziewięć kanonów, które mogą być stosowane w zakresie przestępstw majątkowych. Za tego rodzaju przestępstwa, prawodawca określa kary ferendae sententiae, które mogą być nałożone na sprawcę przestępstwa na drodze przeprowadzonego procesu sądowego lub administracyjnego. Prawodawca nie przewiduje kary latae sententiae za przestępstwa majątkowe.

W przestępstwach symonii i nielegalnych zysków z ofiar mszalnych prawodawca przewiduje karę wymierzenia cenzury. W przypadku symonii jest to sankcja karna obligatoryjna (kan. 1380), natomiast za przestępstwo nielegalnych zysków z ofiar mszalnych jest to sankcja karna fakultatywna (kan. 1385). Do wyjątków dodać należy przestępstwo nadużycia władzy lub zadania, za które prawodawca przewiduje nieokreśloną karę ferendae sententiae, nie wyłączając pozbawienia urzędu (kan. $1389 \$ 1)$.

W pozostałych przypadkach przestępstw majątkowych, prawodawca przewiduje sprawiedliwą karę ferendae sententiae. Są to kary nieokreślone, a ich wymierznie należy do ordynariusza lub sędziego.

\footnotetext{
${ }^{43}$ Por. A. Miziński, Polubowne rozstrzyganie sporów wedtug przepisów Kościoła łacińskiego, Prawo Kanoniczne 55(2012) nr 4, s. 3-20.
} 
Zachować należy prawo partykularne, które w miejsce nieokreślonej kary ferendae sententiae, może ustanowić karę określoną lub obowiązkową (kan. $1315 \$ 1$ ). Zgodnie $\mathrm{z}$ kan. 1317 prawo partykularne nie może ustanowić kary wydalenia ze stanu duchownego.

Partykularne prawo karne winno być jednakowe dla danego terytorium (kan. 1316). Ponadto partykularne prawo karne może także do kar ustanowionych prawem powszechnym za jakieś przestępstwo dołączyć inne, jednak bez poważnej konieczności nie można tego czynić (kan. $1315 \$ 3$ ).

Chcąc wymierzyć karę ferendae sententiae, ordynariusz powinien sam lub przez inną odpowiednią osobę przeprowadzić dochodzenie wstępne, chyba że wydaje się całkowicie zbędne (kan. 1717, \$1). Ordynariusz może dopiero wtedy rozpocząć proces karny gdy uznał, że ani braterskim upomnieniem, ani naganą, ani też innymi środkami pasterskiej troski nie można w sposób wystarczający naprawić zgorszenia, wyrównać naruszonej sprawiedliwości i doprowadzić do poprawy winnego (kan. 1341).

Kanoniczne prawo karne nie rozwiązuje wszystkich przestępstw. Należy też wziąć pod uwagę działalność człowieka, który będąc w różnych sytuacjach życiowych może podejmować decyzje nie zawsze zgodnie z prawem, co nie czyni go usprawiedliwionym.

\section{Canonical penal sanctions for financial malfeasance}

Financial malfeasance, both in the field of administration and alienation of ecclesiastical goods might contribute to financial losses, unnecessary scandal of the faithful, as well as the weakening of public trust. In order to prevent such malfeasance, the Church must seek effective methods which will allow to observe the canon law. The aim of this article was to show the penalties for the financial malfeasance in the canonical legal system.

Interestingly that ecclesiastical legislator does not use the concept of "financial malfeasance". However, we can find nine examples of financial malfeasances in Book VI of the 1983 Code. The following actions can be related to financial malfeasances: 1) impeding the use of ecclesiastical goods (can.1375), 2) invalid alienation of ecclesiastical goods (can. 1377), 3) simony 
(can. 1380), 5) illegitimate profit from Mass offerings (can. 1385), 6) bribery (can. 1386), 7) abuse of authority and culpable negligence in performing act of ecclesiastical power or ministry or office (can. $1389 \$ 1-2$ ), 8) production and use of false documents (can. 1391), 9) clerics carrying out commercial activities (can. 1392).

For such offenses, the legislator determines penalties ferendae sententiae which may be imposed on the offender by judicial or administrative process. The legislator does not provide for penalties latae sententiae for financial malfeasances. For simony and illegitimate profits from Mass offerings legislator provides for a penalty of imposing censure. In the case of simony is mandatory sanction (c. 1380), while for the offense of illegitimate profits from Mass offerings is optional one (can. 1385).

It can be supposed that the most severe penal sanctions for financial malfeasance is deprivation of office that the judge may impose, depending on the severity and harm done. This is an optional penal imposed for abusing of ecclesiastical power or an office (can. $1389 \$ 1$ ). In other cases, the ecclesiastical legislator provides for a just penalty ferendae sententiae. If penalties are indeterminate their imposition belongs to the Ordinary or judge. The particular law is to be observed which in place of indeterminate penalty ferendae sententiae it may establish a penalty determined or obligated (can. $1315 \$ 1$ ). In accordance with can. 1317 particular law can not establish a penalty of dismissal from the clerical state.

SŁOWA KLUCzOWE: przestępstwo, sankcje karne, dobra kościelne

KEYWORDS: offence, penal sanctions, ecclesiastical goods

Nota o Autorze:

Ks. DR PAwee Kaleta - adiunkt w katedrze Norm Ogólnych i Kościelnego Prawa Majątkowego Wydziału Prawa, Prawa Kanonicznego i Administracji Katolickiego Uniwersytetu Lubelskiego Jana Pawła II. 